\title{
Job attitudes as a predictor of work engagement of the lecturing staff at the University of Namibia
}

\begin{tabular}{|c|c|}
\hline \multicolumn{2}{|c|}{$\begin{array}{l}\text { Authors: } \\
\text { Wesley R. Pieters }{ }^{1,2} \\
\text { Ebben van Zyl } \\
\text { Petrus } \mathrm{Nel}^{1}\end{array}$} \\
\hline \multicolumn{2}{|c|}{$\begin{array}{l}\text { Affiliations: } \\
{ }^{1} \text { Department of Industrial } \\
\text { Psychology, University of the } \\
\text { Free State, Bloemfontein, } \\
\text { South Africa }\end{array}$} \\
\hline \multicolumn{2}{|c|}{$\begin{array}{l}{ }^{2} \text { Department Human } \\
\text { Sciences, Psychology Section, } \\
\text { University of Namibia, } \\
\text { Windhoek, Namibia }\end{array}$} \\
\hline \multicolumn{2}{|c|}{$\begin{array}{l}\text { Corresponding author: } \\
\text { Wesley Pieters, } \\
\text { wpieters@unam.na }\end{array}$} \\
\hline \multicolumn{2}{|c|}{$\begin{array}{l}\text { Dates: } \\
\text { Received: } 08 \text { Feb. } 2019 \\
\text { Accepted: } 12 \text { June } 2019 \\
\text { Published: } 29 \text { Oct. } 2019\end{array}$} \\
\hline \multicolumn{2}{|c|}{$\begin{array}{l}\text { How to cite this article: } \\
\text { Pieters, W.R., Van Zyl, E., \& } \\
\text { Nel, P. (2019). Job attitudes } \\
\text { as a predictor of work } \\
\text { engagement of the lecturing } \\
\text { staff at the University } \\
\text { of Namibia. SA Journal } \\
\text { of Human Resource } \\
\text { Management/SA Tydskrif vir } \\
\text { Menslikehulpbronbestuur, } \\
\text { 17(0), a1165. https://doi. } \\
\text { org/10.4102/sajhrm. } \\
\text { v17i0.1165 }\end{array}$} \\
\hline \multicolumn{2}{|c|}{$\begin{array}{l}\text { Copyright: } \\
\text { (C) 2019. The Authors. } \\
\text { Licensee: AOSIS. This work } \\
\text { is licensed under the } \\
\text { Creative Commons } \\
\text { Attribution License. }\end{array}$} \\
\hline \multicolumn{2}{|l|}{ Read online: } \\
\hline 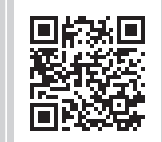 & $\begin{array}{l}\text { Scan this QR } \\
\text { code with your } \\
\text { smart phone or } \\
\text { mobile device } \\
\text { to read online. }\end{array}$ \\
\hline
\end{tabular}

Orientation: Engaged employees contribute to the success and productivity of an organisation. Satisfaction of basic psychological needs and organisational commitment (job attitudes) impact positively on work engagement of the lecturing staff.

Research purpose: The purpose of this study was to investigate the effect of basic psychological need satisfaction and organisational commitment on work engagement of the lecturing staff.

Motivation for the study: Organisations realise their objectives through their employees. When employees are not satisfied or committed at work, it can result in low levels of work engagement, absenteeism, exhaustion, cynicism, low productivity and turnover.

Research approach/design and method: A cross-sectional survey design was used to collect data of the lecturing staff at the University of Namibia $(n=242)$. Cronbach's alpha coefficients, Pearson correlation coefficient and multiple regression analyses were used to analyse the data.

Main findings: This study found a positive relationship between basic psychological need satisfaction, organisational commitment and work engagement. Normative and affective commitment was found to be significant predictors of vigour, dedication and absorption (work engagement).

Practical/managerial implications: Organisations need to include staff members in the decision-making process, allow employees to direct work-related activities, conduct teambuilding activities, provide training and development activities and regularly assess job satisfaction of the employees.

Contribution/value-add: The novelty of this study in Namibia will add to knowledge within industrial or organisational psychology, encourage future research and guide the development of interventions.

Keywords: basic psychological need satisfaction; job attitudes, organisational commitment; work engagement, academic staff.

\section{Introduction}

Coetzee, Schreuder and Tladinyane (2007) found that because of the unstable and ever-changing working environment, employees' motivation, loyalty and morale are negatively affected and may adversely impact their job attitudes and how they engage in their work. The degree to which employees experience work engagement impacts productivity at work. This seems to be the reality for different organisations, including tertiary education institutions.

While doing research in academia, Marques (2013) found that work overload, time pressures and unsupportive supervisors negatively impacted employees' level of work engagement. If employees have the necessary physical and emotional resources to do their work, they become cognitively, emotionally and physically engaged in their work (Janik, 2012). Rothmann, Barkhuizen and Tytherleigh (2008) in their South African study found that academics face high work demands without receiving the necessary job resources. Having a lack of job resources makes employees disengaged or they experience burnout.

The relationship between employees' work-role fit and work engagement was found to be significant. This means that when employees perceive their abilities as matching the job requirements (competence-basic psychological need satisfaction), they would be more engaged with their work (Stander \& Rothmann, 2010; Van Zyl, Deacon, \& Rothmann, 2010). Work engagement predicted affective commitment of university staff (Marques, 2013). This means that if employees are engaged within their work, they will also experience a certain level of 
psychological connection with the organisation and will want to remain with that organisation.

Another factor that related positively to work engagement was the position within the organisation. Position (job level) influenced work engagement significantly. Professors were found to be more dedicated than senior lecturers and more absorbed than junior and senior lecturers (Barkhuizen \& Rothmann, 2006). This could be attributed to the type of work that professors are likely to get involved in. Reaching the level of a professor indicates that the employee has contributed immensely to the discipline or profession. Professors enjoy a reduced teaching load and have more time allocated to developmental activities that tend to be more enjoyable and rewarding when compared to the tasks assigned to junior and senior lecturers.

Resources are important to achieving job success. It was found that employees did not utilise their social and physical coping resources optimally and as a result reported higher levels of depression and anxiety. This was also coupled with their low level of help-seeking behaviour (Pretorius, Basson, \& Ongunbanjo, 2010). When employees are not aware of their work-related stressors or how it affects their overall coping and health, they are less likely to seek help. If employees are exposed to consistently high work demands without having the necessary help-seeking behaviour, they would continuously suffer from depression and anxiety. Experiencing depression or anxiety could result in lower performance or even absenteeism because of illness (Pretorius et al., 2010). These employees are likely to leave the organisation.

Du Plooy and Roodt (2010) found a negative relationship between work engagement and turnover intention. This means that when employees are actively engaged in the work of the organisation (experiencing vigour, dedication and absorption), they are less likely to experience turnover intention. Takawira, Coetzee and Schreuder (2014) in their study of academic staff members in South Africa also found a positive relation between work engagement and job embeddedness and a negative relation with turnover intention.

Based on the literature discussed, it is hypothesised that because of the regular changes in academia, employees' level of motivation and loyalty is negatively affected. With these regular changes, employees' workload is negatively affected and working without the needed job resources impacts the overall work engagement of employees. It was also noted that the level of work-role fit and position of employees impact their level of work engagement. When employees experience work engagement, they become more committed to the organisation. On the contrary, when employees work without the needed job resources, they experience anxiety, depression, low levels of work engagement and ultimately turnover intention.

\section{Purpose}

This study is exploratory in nature as it is aimed at investigating the effect of basic psychological need satisfaction and organisational commitment on work engagement of the lecturing staff at the University of Namibia (UNAM). Being able to establish a relationship between job attitudes and work engagement will assist the university to develop interventions that could ensure employees remain engaged and productive.

\section{Literature review}

\section{Basic psychological need satisfaction, organisational commitment and work engagement}

Ryan and Deci (2000) explained that basic psychological need satisfaction (autonomy, relatedness or belongingness and competence) is an important requirement for growth with regard to integrity and health. Autonomy, as explained under the job characteristic model of work motivation, is characterised by how much independence employees have when deciding about how to execute their work tasks or goals; how to make decisions regarding the work; and how to plan, schedule and execute these duties (Greenberg, 2011). The need for relatedness has to do with feeling connected to others within the organisation, a sense of communion, and developing close and intimate relations with others (Deci \& Ryan, 2008; Verstuyf, Vansteenkiste, Soenens, \& Boene, 2013). Verstuyf et al. (2013) defined competence as the need to feel efficient and capable of reaching desired outcomes. When employees meet the requirements of their jobs and successfully execute their work duties, they satisfy the need for competence (Viljoen \& Rothmann, 2009). Apart from exploring the impact of basic psychological need satisfaction on work engagement, this study will also explore the impact of organisational commitment on work engagement.

Organisational commitment has been defined as the psychological link that employees have with the organisation, identifying with the organisation and its goals, exerting more effort towards the completion of tasks, making personal sacrifices and wanting to remain with that particular organisation (Allen \& Meyer, 1996; Luthans, 2005). Meyer, Allen and Smith (1993) characterised organisational commitment by three dimensions: continuance, normative and affective commitment. Continuance commitment is explained as employees' commitment towards the organisation because of the costs associated with leaving. Normative commitment deals with employees' desire to stay because of a perceived obligation, remaining because the organisation has paid for further studies or a medical procedure. Affective commitment is the psychological identification and emotional attachment towards the organisation and working towards achieving the goals and objectives of the organisation (Meyer et al., 1993). Before discussing the relationship between basic psychological need satisfaction and work engagement or the relationship between organisational commitment and work engagement, it is necessary to clearly define work engagement.

Work engagement is defined as a positive, fulfilling and affective emotional state characterised by vigour, dedication and absorption (Bakker, Schaufeli, Leiter, \& Taris, 2008). 
Engagement has also been defined as a motivating force that pushed employees to higher levels of performance. This force includes the attitudes and feelings towards the organisation and the work that employees do (Wellins \& Concelman, 2007). Engaged employees are characterised as feeling involved, committed, passionate and empowered. These employees also display these feelings and emotions in their behaviour and in the work that they do (Mone \& London, 2010). Vigour can be defined as high levels of energy and mental resilience while working (Schaufeli, 2014). These employees continue to work even when the tasks become somewhat difficult. Dedication can be defined as the pride, self-worth and identity experienced when doing work (Bakker, 2011). These employees regard the work that they do as important and meaningful. Absorption is defined as the ability to be fully taken in by work activities, staying focussed, working without realising the time pass and stopping only once they are done with the assigned tasks (Bakker \& Demerouti, 2008, Schaufeli, 2014).

Katsaros, Tsirikas and Bani (2014) explain that job attitudes are employees' overall assessment of their feelings and beliefs regarding their jobs and how committed they are towards the organisation. Despite the conceptual and empirical distinctions between basic psychological need satisfaction (as part of job satisfaction) and organisational commitment (Tett \& Meyer, 1993), it was also found that there are indeed theoretical and empirical commonalities between these variables. Hulin (1991) and Weiss (2002) supported this perspective and found considerable theoretical overlap, indicating that the only clear difference was the conceptual target. It was observed that basic psychological need satisfaction targets the position or work role within organisational commitment that encompasses the entire organisation.

It was also found that affective commitment is both a consequence and correlate of job satisfaction (including basic psychological need satisfaction). This also emphasises the strong link between job satisfaction and organisational commitment, not only from a theoretical perspective of view but also from an empirical one (Schleicher, Hansen, \& Fox, 2010). Harrison, Newman and Roth (2006) maintained that basic psychological need satisfaction and organisational commitment should be regarded as job attitudes owing to their fundamental evaluation of the job experiences. The positive relationship between basic psychological need satisfaction and organisational commitment is also important to understanding the collective impact on work engagement.

Kovjanic, Schuh and Jonas (2013) found that when employees experience positive attitudes towards their jobs (satisfaction in terms of autonomy, relatedness and competence), they will also be more likely to experience commitment, working towards the goals of the organisation and possibly improving productivity levels. A direct positive impact was found between basic psychological need satisfaction and organisational commitment and indirectly on job performance. This emphasises the importance of how basic psychological need satisfaction will impact employees' commitment and ultimately their level of job performance (Fu \& Deshpande, 2014). This was also supported by Afzaal and Afzaal (2013) and Rokhman (2014) recording positive results between basic psychological need satisfaction and organisational commitment. Ajala (2013) found that when employees are given the necessary supportive working environment (relatedness), they would also experience a higher level of basic psychological need satisfaction, good health and affective commitment. When the organisation provides a supportive working environment, which caters to the needs and interests of the employees, the level of emotional identification of employees would be enhanced, resulting in them wanting to work harder, going beyond the call of duty.

Educators who experience higher levels of autonomy (basic psychological need satisfaction) were also found to be more committed towards the organisation. This could be attributed to employees experiencing a higher psychological link, feeling part of the organisation (relatedness) as opposed to employees who do not experience a sense of autonomy in their work (Janik, 2012). It was found that poor relations with coworkers (relatedness) negatively influenced employees' level of organisational commitment (Janik, 2012; Marques, 2013). Having unhealthy relations with colleagues could result in lower levels of commitment. Dockel, Basson and Coetzee (2006) indicated that negative relations at work also negatively impact employees' motivation to effectively contribute to the success of the organisation.

\section{The relationship between job attitudes and work engagement}

Vansteenkiste et al. (2007) highlighted some studies that indicate that when employees satisfied their basic needs (need for autonomy, belongingness and competence), they were likely to experience positive work outcomes such as job commitment, job attitude, self-esteem and general health. When one looks at these findings, it seems likely that satisfying the basic psychological needs may also enhance employees' level of engagement, reduce turnover intention and improve their overall health.

Janik (2012) found a positive correlation between emotional engagement, cognitive engagement and organisational commitment. This indicates that when employees are doing work that gives meaning to their lives, they feel like they are making an impact in the work that they do and they are also more likely to become more committed to the organisation (Sardeshmukh, Sharma, \& Golden, 2012).

Saks (2006) also found a positive relationship between work engagement and organisational commitment (affective). It was noted that affective commitment is instrumental in achieving higher levels of productivity within the organisation. Another study by Simons and Buitendach (2013) also found a positive correlation between work engagement and organisational commitment. It was indicated that these variables have a reciprocal relationship, 
meaning that they both influence each other positively. The more the employees become committed to the organisation, the more likely they will become engaged and vice versa.

Based on the cognitive evaluation theory by Ryan and Deci (2000), employees' level of motivation is influenced by social and working environmental factors. When employees evaluate the factors within the working environment (feedback, communication, autonomy, social context) as favourable, they are likely to experience motivation, performance, competence, well-being and organisational commitment. If the evaluation is negative, employees are likely to experience demotivation, disempowerment, poor performance, poor well-being and lack of commitment. Employees require their basic psychological needs to be satisfied; through this satisfaction, they are likely to become more committed to the organisation and ultimately work towards the goals and objectives of the organisation (work engagement).

\section{The outcomes of job attitudes and work engagement}

It has been found that when an organisation has employees who experience positive job attitudes, this impacts positively on several levels. Firstly, it impacts their level of commitment towards the organisation (Mosadeghrad \& Ferdosi, 2013); secondly, it fosters emotions where employees wish to remain attached to the organisation (Mensele \& Coetzee, 2014); thirdly, it negates the pressure from work demands (Sardeshmukh et al., 2012) and finally, it means that employees are more likely to be positive about their abilities to complete their work tasks effectively while being more engaged in their work (Stander \& Rothmann, 2010).

Field and Buitendach (2011) found that employees who experience work engagement will become more committed (affective commitment). These employees will experience higher levels of well-being. This means that if organisations can enhance employees' level of commitment, they will become more committed towards the organisation and experience higher levels of well-being. Bakker et al. (2008) found that employees who experience engagement are less likely to experience exhaustion and cynicism (burnout).

Having healthy work relations acts as a coping mechanism when dealing with work and personal stress (Oosthuizen \& Berndt, 2008). Based on these findings, it makes sense to predict that if employees experience feelings of relatedness (basic psychological need satisfaction) and links (job embeddedness), they would also be able to cope better with the constant and ever-taxing working environment of academic staff members (Manger \& Eikeland, 1990). This can also be considered in terms of the job demands-resources model of work engagement that explains the importance of how job resources positively help employees to cope better with job demands. The feelings of relatedness and collegial relations act as resources for employees to handle greater job demands and prevent further job stress. Relations with coworkers (links-job embeddedness) had a negative relation with turnover intention. This means that when employees have good relations with fellow employees, they would also be less likely to want to leave the organisation (Chang, Wang, \& Huang, 2013).

Bakker (2011) found that engaged employees are more likely to create their own resources by asking for feedback from supervisors. Engaged employees are more likely to engage in job crafting, adapting their needs with their personal knowledge, skills and abilities. In an effort to remain engaged, engaged employees might increase their job demands by taking on new projects to create more challenging work.

When employees experience engagement, they experience vigour, dedication and absorption in their work. Having the necessary job resources allows employees to become engaged in their work, but it also increases their level of job performance. This indicates that engaged employees contribute more effectively to the production and effectiveness of the organisation (Bakker, 2011). Joshi and Sodhi (2011) in their study conducted in India also observed that work engagement has a direct impact on employee performance and business outcomes.

Bakker (2011) found that engaged employees are more likely to be open to new information, more productive and willing to do more. Being open to new information allows employees to become more informed and might even influence their skills and abilities regarding the job. Organisational citizenship behaviour (OCB) is behaviour that is voluntarily engaged into by employees without expecting compensation, and these duties are not necessarily part of the employees' job description (Mohamed, 2016). Engaging in OCB, employees are also more likely to experience positive relations with colleagues and supervisors, improve mastery of tasks and become more competent.

Based on the literature discussed, basic psychological need satisfaction (autonomy, relatedness, competence) related positively to organisational commitment (affective normative, continuance). When employees' basic psychological needs are satisfied, employees prefer to remain at the organisation and work towards achieving the goals and objectives of the organisation. Basic psychological need satisfaction and organisational commitment positively impact work engagement levels of employees. If these needs of employees are satisfied, they remain with the organisation, contribute towards the success of the organisation, function efficiently even when work resources are limited, experience positive health and increase the productivity of the organisation.

Figure 1 presents the expected relationship between basic psychological need satisfaction and work engagement, organisational commitment and work engagement, and also the relationship between basic psychological need satisfaction and organisational commitment impacting work engagement.

Based on the literature discussed, the following hypotheses have been developed: 


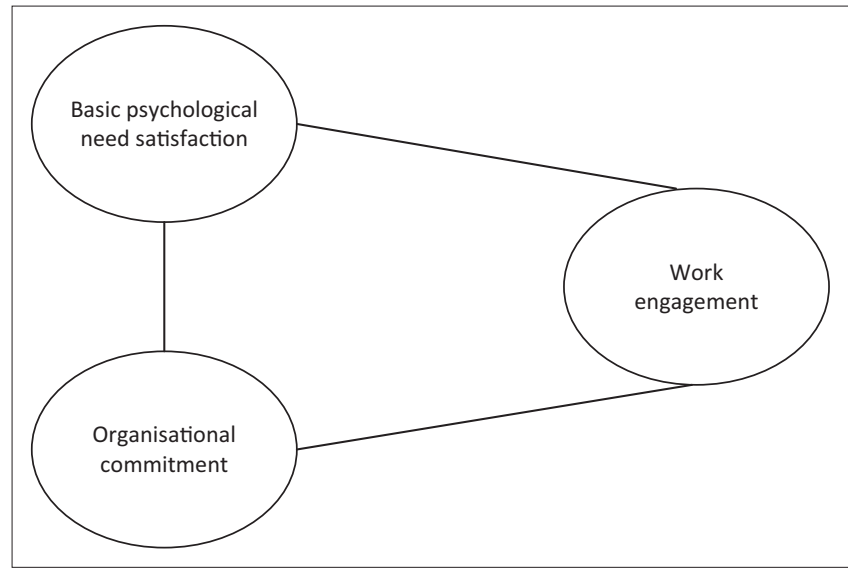

FIGURE 1: Theoretical relationship between basic psychological need satisfaction, organisational commitment and work engagement.

Hypothesis 1: Job attitudes (basic psychological need satisfaction) have a positive relationship with work engagement.

Hypothesis 2: Job attitudes (organisational commitment) have a positive relationship with work engagement.

Hypothesis 3: Job attitudes (basic psychological need satisfaction and organisational commitment) are significant predictors of work engagement.

\section{Research design \\ Research approach}

Making use of a questionnaire, a cross-sectional research design was used to collect data on the biographical variables of employees, basic psychological need satisfaction, organisational commitment and work engagement (Creswell, 2003). Making use of questionnaires allowed the researchers to access a large number of participants and gather information on a variety of attitudes.

\section{Participants}

The study made use of the lecturing staff at the UNAM. Questionnaires were delivered to the offices of the lecturers and collected after a few days. There is a total of 771 academics employed at UNAM, not all into lecturing. Making use of convenience sampling, the lecturers who were available and willing to participate were approached. Convenience sampling can be very useful, especially when time, resources and human resources are limited (Etikan, Musa, \& Alkassim, 2015). A total of 300 questionnaires were distributed and 242 useable questionnaires returned ( $81 \%$ response rate).

Participants comprised 128 females (52.9\%) and 114 males (47.1\%). The rest of the biographical details are presented in Table 1.

\section{Measuring instruments}

The biographical information was collected using a questionnaire developed by the researchers to get information regarding the participants' gender, age, tenure at UNAM, highest qualification obtained, marital status, number of dependents and position within the organisation.
TABLE 1: Biographical details of the sample.

\begin{tabular}{|c|c|c|}
\hline Description & Frequency & Percentage \\
\hline \multicolumn{3}{|l|}{ Sex } \\
\hline Male & 114 & 47.1 \\
\hline Female & 128 & 52.9 \\
\hline \multicolumn{3}{|l|}{ Age (years) } \\
\hline $24-28$ & 12 & 5.0 \\
\hline 29-31 & 10 & 4.1 \\
\hline $32-35$ & 31 & 12.8 \\
\hline $36-40$ & 37 & 15.3 \\
\hline $41-45$ & 23 & 9.5 \\
\hline $46-50$ & 31 & 12.8 \\
\hline 51 and older & 97 & 40.1 \\
\hline Missing values & 1 & 0.4 \\
\hline \multicolumn{3}{|l|}{ Tenure (UNAM) } \\
\hline Less than 1 year & 25 & 10.3 \\
\hline $1-2$ years & 31 & 12.8 \\
\hline $3-4$ years & 31 & 12.8 \\
\hline $5-6$ years & 55 & 22.7 \\
\hline $7-8$ years & 16 & 6.6 \\
\hline 9 years and more & 81 & 33.5 \\
\hline Missing values & 3 & 1.2 \\
\hline \multicolumn{3}{|l|}{ Marital status } \\
\hline Single & 75 & 31.0 \\
\hline Married & 148 & 61.2 \\
\hline Divorced & 11 & 4.5 \\
\hline Widowed & 8 & 3.3 \\
\hline \multicolumn{3}{|c|}{ Highest qualification obtained } \\
\hline Honours degree & 29 & 12.0 \\
\hline Master's degree & 129 & 53.3 \\
\hline PhD & 72 & 29.7 \\
\hline Postdoctoral & 12 & 5.0 \\
\hline \multicolumn{3}{|l|}{ Rank } \\
\hline Assistant lecturer & 26 & 10.7 \\
\hline Lecturer & 156 & 64.5 \\
\hline Senior lecturer & 36 & 14.9 \\
\hline Associate professor & 15 & 6.2 \\
\hline Full professor & 9 & 3.7 \\
\hline \multicolumn{3}{|c|}{ Number of dependents } \\
\hline None & 56 & 23.1 \\
\hline $1-2$ & 100 & 41.3 \\
\hline $3-4$ & 66 & 27.3 \\
\hline $5-6$ & 12 & 5.0 \\
\hline 7-9 & 5 & 2.1 \\
\hline 10 and more & 2 & 0.8 \\
\hline Missing values & 1 & 0.4 \\
\hline Total & 242 & 100 \\
\hline
\end{tabular}

UNAM, University of Namibia.

The Work-Related Basic Psychological Need Satisfaction Scale (W-BNS) was developed by Van den Broeck, Vansteenkiste, De Witte and Lens (2008). The questionnaire assesses needs related to autonomy, competence and relatedness. Example items include the following: autonomy - 'I feel free to do my job the way I think it could best be done'; competence - 'I feel competent in my job' and relatedness - 'At work I feel part of a group'. The questionnaire makes use of 18 items and a 5-point response scale (1 - strongly disagree to 5 - strongly agree). Rothmann, Diedericks and Swart (2013) found reliablility for autonomy (0.78), competence (0.82) and relatedness (0.86). Discriminant, criterion-related and predictive validity was found for the three-factor structure of 
basic psychological need satisfaction instrument (Van den Broeck, Vansteenkiste, De Witte, Soenens, \& Lens, 2010).

The Organisational Commitment Questionnaire (OCQ) was developed by Allen and Meyer (1996) to assess the employees' level of commitment to the organisation. The questionnaire made use of 18 items (six items for each scale), measuring normative, effective and continuance commitment (Brown, 2003). The response scale made use of a Likert response scale from 1 to 5 (1-strongly disagree to 5-strongly agree), measuring continuance - 'one of the few negative consequences of leaving this organisation would be the scarcity of available alternatives'; normative - 'I would feel guilty if I leave my organisation right now' and affective commitment - 'I do not feel like "part of the family" at my organisation'. Reliability was recorded for affective commitment (0.71), normative commitment (0.71) and continuance commitment (0.71) (Pieters, 2015). Khan, Awang and Ghouri (2014) found this instrument to be a valid measure for organisational commitment.

The Utrecht Work Engagement Scale (UWES) has been developed by Schaufeli and Bakker (2004). This questionnaire measures vigour - 'I am bursting with energy in my work'; dedication - 'I find the work that I do full of meaning and purpose' and absorption - 'Time flies when I am working'. This self-report questionnaire response scale ranges from 0 (never) to 7 (always) with 17 items across the different dimensions. The UWES recorded Cronbach's alphas of 0.78-0.91 (Janik, 2012). Seppala et al. (2008) found good construct validity for the instrument.

\section{Design}

This study made us aware of the survey method, using questionnaires to collect the data. The data were analysed using the Statistical Package for the Social Science (SPSS), participant information was kept confidential and participants were in no way harmed. The questionnaires are kept in a safe place for safety and future consideration.

\section{Procedure}

After obtaining permission from the Research and Publication office at the UNAM, participants were approached to participate in the study. After explaining the purpose and objectives of the study, participants signed a consent form, indicating that they are participating willingly, may withdraw from the study at any time and were in no way coerced into participating. Questionnaires were distributed at the different offices of lecturing staff and collected a few days later. Participants were thanked for their time and questionnaires were stored away in a safe place.

\section{Analysis}

It is expected that basic psychological need satisfaction and organisational commitment will have a positive relationship with work engagement. Basic psychological need satisfaction and organisational commitment are expected to significantly predict work engagement of lecturing staff. Statistical Package for the Social Science Version 24.0 (SPSS, 2016) was used to analyse the data. Cronbach's alpha coefficients and Pearson's correlation coefficients were used to determine the relationship between the variables. Descriptive statistics were reported. Multiple regression analyses were used to investigate whether job attitudes (basic psychological need satisfaction and organisational commitment) predicted work engagement. Considering the correlation between affective and normative commitment, multicollinearity does not exist because the correlation is below $r=0.9$, as explained by Pallant (2005).

\section{Ethical consideration}

Ethical approval for the study was obtained from the Faculty of Economic and Management Sciences Ethics Committee (Ethical clearance number: UFS-HSD2015/0562).

\section{Results \\ Descriptive statistics and correlations}

The means, standard deviation (SD), Cronbach's alpha and correlations were analysed and recorded in Table 2.

The following mean scores were reported: autonomy (21.55), relatedness (21.78), competence (17.27); affective commitment (21.35), continuance (17.12), normative commitment (19.95); vigour (28.96), dedication (24.66) and absorption (28.32). The following SD scores were reported: autonomy (4.23), relatedness (3.24), competence (2.08); affective commitment (4.34), continuance (4.65), normative commitment (4.47); vigour (5.57), dedication (5.05) and absorption (6.45).

Cronbach's alphas were reported for autonomy (0.78), relatedness (0.81) and competence (0.81). Cronbach's alphas were recorded for continuance $(0.75)$, normative commitment (0.77) and affective commitment (0.80). Work engagement reported Cronbach's alphas for vigour (0.81), dedication (0.81) and absorption (0.82). It is clear from the results that all the scales are reliable; they concurred with Nunnally's (1978) estimates of 0.70 and above.

Table 2 depicts the positive relationship between the dimensions of basic psychological need satisfaction, organisational commitment and work engagement. This indicates that when employees experience satisfaction in terms of basic psychological need satisfaction, they are likely to become more committed towards the organisation and experience a higher level of work engagement. Continuance commitment reported some negative relationships. Specific correlations are presented in the Table 2.

\section{Multiple regression analyses}

Multiple regression analyses were carried out to test hypothesis 3 . In model 1, vigour (work engagement) was used as the dependent variable, with normative and affective 
TABLE 2: Descriptive statistics and Pearson correlation coefficient.

\begin{tabular}{|c|c|c|c|c|c|c|c|c|c|c|c|c|}
\hline Variable & M & SD & $\alpha$ & 1 & 2 & 3 & 4 & 5 & 6 & 7 & 8 & 9 \\
\hline 1. Basic psychological need satisfaction-autonomy & 21.55 & 4.23 & 0.78 & - & - & - & - & - & - & - & - & - \\
\hline 2. Basic psychological need satisfaction-relatedness & 21.78 & 3.24 & 0.81 & $0.28 *$ & - & - & - & - & - & - & - & - \\
\hline 3. Basic psychological need satisfaction-competence & 17.27 & 2.08 & 81 & $0.21 *$ & $0.23 *$ & - & - & - & - & - & - & 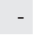 \\
\hline 4. Affective commitment & 21.35 & 4.34 & 0.80 & $0.47 * * *$ & $0.35 * * *$ & $0.25 *$ & - & - & - & - & - & - \\
\hline 5. Continuance commitment & 17.12 & 4.65 & 0.75 & $-0.19 *$ & $-0.05 *$ & $-0.14 *$ & $-0.13 *$ & - & - & - & - & - \\
\hline 6. Normative commitment & 19.95 & 4.47 & 0.77 & $0.26^{*}$ & $0.16^{*}$ & $0.10^{*}$ & $0.61 * * *$ & $0.14 *$ & - & - & - & - \\
\hline 8. Work engagement - dedication & 24.66 & 5.05 & 0.81 & $0.24 *$ & $0.25 *$ & $0.23 *$ & $0.49 *, * *$ & $-0.12^{*}$ & $0.42^{*, * *}$ & $0.81 * * *$ & - & - \\
\hline 9. Work engagement - absorption & 28.32 & 6.45 & 0.82 & $0.12 *$ & $0.20 *$ & $0.20 *$ & $0.38^{* * * *}$ & $-0.11 *$ & $0.35^{*, * *}$ & $0.78 * * *$ & $0.77 * * *$ & - \\
\hline
\end{tabular}

SD, standard deviation.

*, Statistically significant: $p \leq 0.05$

**, Practically significant correlation (medium effect): $0.30 \leq r \leq 0.49$.

$* * *$, Practically significant correlation (large effect): $r \geq 0.50$.

TABLE 3: Multiple regression with vigour (work engagement) being the dependent variable and normative and affective commitments (organisational commitment) the dependent variables.

\begin{tabular}{lcccccccc}
\hline Model & \multicolumn{2}{c}{$\begin{array}{c}\text { Unstandardised } \\
\text { coefficients } \\
\text { Beta SE }\end{array}$} & $\begin{array}{c}\text { Standardised } \\
\text { coefficients } \\
(\boldsymbol{\beta})\end{array}$ & $\boldsymbol{t}$ & $\boldsymbol{p}$ & $\boldsymbol{F}$ & $\boldsymbol{R}^{\mathbf{2}}$ & $\boldsymbol{\Delta} \boldsymbol{R}^{\mathbf{2}}$ \\
\hline (Constant) & 17.10 & 1.76 & - & 9.73 & 0.00 & 23.87 & 0.166 & 0.160 \\
AFF & 0.41 & 0.10 & 0.32 & 4.24 & $0.00 * *$ & - & - & - \\
NORM & 0.16 & 0.09 & 0.13 & 1.72 & 0.09 & - & - & - \\
\hline
\end{tabular}

$t$, test; $p$, probability value; $F$, overall significance; $R^{2}$, percentage variance explained; $\Delta R^{2}$, change in percentage variance explained; $B$, regression coefficient; $\mathrm{SE}$, standard error; AFF, affective commitment; NORM, normative commitment.

$*, p \leq 0.05 ; * *, p \leq 0.01$.

commitments as the independent variables in step 1 . Autonomy, relatedness, competence and continuance commitment were excluded from the analysis because these dimensions do not meet the expected correlation of $r=0.3$ (Pallant, 2005). The results are reported in Table 3.

As can be seen from Table 3, entry of normative and affective commitments at the first step of the regression analysis produced a statistically significant model $\left(F_{(2,239)}=23.87\right.$; $p<0.00)$ and account for $16 \%$ of the variance. It appears that affective commitment $(\beta=0.32 ; t=4.24 ; p<0.00)$ is a significant predictor of vigour (work engagement). Normative commitment was reported as an insignificant predictor of vigour (work engagement) ( $\beta=0.13 ; t=1.72$; $p<0.09)$.

Multiple regression analyses were performed. The first model that was analysed used dedication (work engagement) as the dependent variable with normative and affective commitment as the independent variables (model 1). The results are reported in Table 4.

As can be seen from Table 4, entry of normative and affective commitments at the first step of the regression analysis produced a statistically significant model $\left(F_{(2,239)}=42.40\right.$; $p<0.00)$ and accounts for $25.6 \%$ of the variance. It appears that normative commitment $(\beta=0.19 ; t=2.66 ; p<0.01)$ and affective commitment $(\beta=0.38 ; t=5.35 ; p<0.00)$ are significant predictors of dedication (work engagement).

Multiple regression analyses were performed. The first model analysed and used dedication (work engagement) as the dependent variable and normative and affective
TABLE 4: Multiple regression with dedication (work engagement) being the dependent variable and normative and affective commitments (organisational commitment) the dependent variables.

\begin{tabular}{lccccccccc}
\hline Model & \multicolumn{2}{c}{$\begin{array}{c}\text { Unstandardised } \\
\text { coefficients } \\
\text { Beta SE }\end{array}$} & $\begin{array}{c}\text { Standardised } \\
\text { coefficients } \\
(\boldsymbol{\beta})\end{array}$ & $\boldsymbol{t}$ & $\boldsymbol{p}$ & $\boldsymbol{F}$ & $\boldsymbol{R}^{\mathbf{2}}$ & $\boldsymbol{\Delta} \boldsymbol{R}^{\mathbf{2}}$ \\
\hline (Constant) & 11.13 & 1.50 & - & 7.43 & 0.00 & 42.40 & 0.262 & 0.256 \\
AFF & 0.44 & 0.08 & 0.38 & 5.35 & $0.00^{* *}$ & - & - & - \\
NORM & 0.21 & 0.08 & 0.19 & 2.66 & $0.01^{*}$ & - & - & - \\
\hline
\end{tabular}

$t$, test; $p$, probability value; $F$, overall significance; $R^{2}$, percentage variance explained $\Delta R^{2}$, change in percentage variance explained; $B$, regression coefficient; $\mathrm{SE}$, standard error; AFF, affective commitment; NORM, normative commitment.

$*, p \leq 0.05 ; * *, p \leq 0.01$.

TABLE 5: Multiple regression with absorption (work engagement) being the dependent variable and normative and affective commitments (organisational commitment) the dependent variables.

\begin{tabular}{lcccccccc}
\hline Model & \multicolumn{2}{c}{$\begin{array}{c}\text { Unstandardised } \\
\text { coefficients } \\
\text { Beta SE }\end{array}$} & $\begin{array}{c}\text { Standardised } \\
\text { coefficients } \\
(\boldsymbol{\beta})\end{array}$ & $\boldsymbol{t}$ & $\boldsymbol{p}$ & $\boldsymbol{F}$ & $\boldsymbol{R}^{\mathbf{2}}$ & $\boldsymbol{\Delta} \boldsymbol{R}^{\mathbf{2}}$ \\
\hline (Constant) & 14.64 & 2.04 & - & 7.18 & 0.00 & 23.33 & 0.163 & 0.156 \\
AFF & 0.39 & 0.11 & 0.26 & 3.48 & $0.00^{* *}$ & - & - & - \\
NORM & 0.27 & 0.11 & 0.19 & 2.51 & $0.01^{*}$ & - & - & - \\
\hline
\end{tabular}

$t$, test; $p$, probability value; $F$, overall significance; $R^{2}$, percentage variance explained $\Delta R^{2}$, change in percentage variance explained; $B$, regression coefficient; $\mathrm{SE}$, standard error; $\Delta R^{2}$, change in percentage variance explained; $B$, regression
$\mathrm{AFF}$, affective commitment; NORM, normative commitment.

$*, p \leq 0.05 ; * *, p \leq 0.01$.

commitments as the independent variables (model 1). The results are reported in Table 5.

As can be seen from Table 5, entry of normative and affective commitments at the first step of the regression analysis produced a statistically significant model $\left(F_{(2,239)}=\right.$ 23.33; $p<0.00)$ and accounts for $15.6 \%$ of the variance. It appears that normative commitment $(\beta=0.19 ; t=2.51$; $p<0.01)$ and affective commitment $(\beta=0.26 ; t=3.48$; $p<0.00$ ) are significant predictors of absorption (work engagement).

\section{Discussion \\ Outline of the results}

Hypothesis 1 of the study investigated the relationship between job attitudes (basic psychological need satisfaction) and work engagement. Autonomy, relatedness and competence reported positive relationships with vigour, dedication and absorption, supporting hypothesis 1 . These findings are also supported by Fu and Deshpande (2014) and 
Brinkmann and Stapf (2005). When employees are included in decision-making process, they would persevere more than employees who are excluded from the decision-making process, and they would also be more hopeful about their impact. Being included or allowed to direct work-related activities will also enhance the perceived level of significance of lecturers and possible improved acceptance and implementation of critical decisions. The self-determination theory (Deci \& Ryan, 2008) demonstrates that when employees experience satisfaction regarding their need for autonomy, relatedness and competence, they would also experience autonomous motivation impacting engagement at work. Employees who experience autonomous motivation can direct and control their own behaviour to the extent that these employees experience pleasure, persevere and perform effectively, even when it comes to complex tasks. These employees would also experience a higher level of competence, task significance and psychological meaningfulness in their work (Baklaieva, 2016), and all these are negatively related to turnover intention. When employees have the required job resources, including autonomy, they would be less likely to want to leave (Viljoen \& Rothmann, 2009).

Having good relations with colleagues and supervisors enhances commitment of employees that they identify with the organisation, ensuring that they would be able to work harder for longer because they feel part of the organisation (Chang et al., 2013). Having good relations with colleagues increases the chances of being assisted when asking for help. Employees who are competent in what they do experience mastery and pride in their work. Experiencing mastery in one's work encourages employees take on more tasks, challenging tasks, and persevere even when faced with difficulty.

Hypothesis 2 investigated the positive relationship between job attitudes (organisational commitment) and work engagement. The results of this study supported the positive relationship between organisational commitment and work engagement. Janik (2012) and Sardeshmukh et al. (2012) also found a positive relationship between the variables. Allen and Meyer (1990) found that competence impacted positively on affective commitment. Identifying with the goals and objectives of the organisation makes employees want to work towards the success of the organisation. When employees are provided with the needed resources, experience job satisfaction and support from the organisation, they are likely to want to remain part of the organisation (normative commitment). When employees are provided with good benefits and salaries, they would experience continuance commitment because the work opportunities outside the organisation are not as attractive as that of their current organisation. In this way, organisations can retain their top talent.

Normative and affective commitment predicted vigour, dedication and absorption (work engagement). These results support hypothesis 3 of the study. When organisations provide employees with enough job resources, good benefits and salaries, they are likely to want to remain in the organisation. Employees would feel obligated to work towards the goals and objectives of the organisation. Knowing that the organisation looks after the needs of the employees, employees would continue to work hard, persevere and remain engaged until their tasks are completed. Identifying with the organisation's goals and objectives makes it easier to execute work duties because it does not conflict with employees' values and beliefs. Affective commitment can be regarded as the desire component that is persistent and crucial within organisational commitment and for organisational effectiveness (Mercurio, 2015). This study supports this view that emphasises the importance and effectiveness of affective commitment.

\section{Practical implications}

Autonomy, relatedness and competence were found to have some of the stronger relations with organisational commitment, specifically affective and normative commitments. Affective and normative commitments were found to be significant predictors of vigour, dedication and absorption (work engagement). By enhancing basic psychological need satisfaction (autonomy, relatedness and competence), employees would become more committed towards the organisation, more engaged and improve on productivity.

To enhance autonomy, employees should be included in decision-making. Certain platforms should be availed to ensure that the lecturing staff can air their concerns and provide insight. Being included in the decision-making process allows for a better understanding and implementation of these decisions. Having a top-down approach to decision-making can frustrate employees and make implementation of these decisions difficult. At UNAM, employees are represented at some levels where decision-making takes place; however, more inclusion into the process could only benefit the implementation of decisions, productivity and work engagement of lecturers.

To enhance relatedness among staff members, regular teambuilding sessions should be conducted. Lecturing staff members have different teaching schedules and rarely meet each other. These staff members are likely to only meet at meetings or when accidentally running into each other in the passages. Through team-building exercises, lecturing staff can get to know each other and how to better interact with each other. Knowing what kind of person a colleague is will allow for improved interaction and understanding of each other and approaches to dealing with different situations. Knowing one's colleagues better will also allow for improved conflict resolution and the possible prevention of conflict. Having good relations with colleagues will also enhance group synergy, departmental success and productivity. Good relations with colleagues can enhance the negotiations regarding teaching load or modules. Employees would also be more willing to assist each other when a colleague needs to attend to a person's emergency or during work-related absence.

Employees should be allowed to improve their skills and abilities. The lecturing staff can enhance their competence through workshops, seminars, lectures, conferences or 
training sessions. Employees should be assisted to develop a career plan; they should identify as to where they would like to be in the next 3-5 years and what training or development they would need to achieve their goals. Supervisors and the organisation should ensure that the aims of the employees are in line with the organisation's goals and objectives. Supervisors and organisations should plan and provide the needed resources and support to help employees realise these goals. Succession planning should be taken seriously and implemented. Being an understudy can expose employees to opportunities to enhance their skills and abilities.

To improve work engagement of employees, all teaching staff should experience autonomy, exposure to various skills, task significance, feedback and task identification. This means that the staff should be included in decision-making, allowed to decide how to execute their work-related duties and to utilise different skills, experience meaning in the work they do, receive feedback on work done and get to know their level of performance. Academics should be paid equitable salaries and benefits; the inputs and outcomes of the job determine the importance and significance of the job. If education is the tool to alleviate poverty and enhance economic emancipation, institutions of higher learning and governmental organisations should budget and reward these academics accordingly. Communication, specifically about performance, needs to be communicated openly and effectively. Many organisations do performance evaluation because it is a requirement at the workplace instead of identifying the value it has for the employee and the organisation. Employees need to be informed regularly about work-related activities within the workplace and know what is expected of them in the organisation.

Considering that job satisfaction is positively related to affective commitment, it is recommended that UNAM regularly evaluate employees' level of job satisfaction and gauge what it is that would guarantee employee satisfaction. Managers and supervisors within the university also need to ensure transparency and fairness within the organisation. When employees see their supervisors or managers engaging in equitable and transparent practices, they would also identify with the organisation and want to work towards the success of the organisation (affective commitment). Affective commitment is also regarded as the strongest significant predictor of turnover intention, highlighting the importance of trying to nurture this feeling.

\section{Limitations and recommendations}

Some of the limitations experienced when conducting this study were limited access to the staff members. Some campuses are located long distances from the central region, making it more challenging to obtain a representative sample.

This study may also include specific aspects related to job satisfaction by focussing on the different domains of job satisfaction such as satisfaction with pay and benefits, nature of work or advancement opportunities. Job satisfaction was found to be positively related to organisational commitment and work engagement.
Future studies could explore job satisfaction as part of the factors that impact work engagement. A longitudinal study could also help to see if the results of this study are true over time. Considering the challenges with making use of questionnaires alone, future studies could explore the option of conducting interviews or observations about the levels of work engagement of the lecturing staff. Perhaps, future studies could also focus on developing interventions and test how these suggestions may improve work engagement of academics at UNAM.

\section{Conclusion}

This study found positive relationships between basic psychological need satisfaction and organisational commitment, basic psychological need satisfaction and work engagement, and organisational commitment and work engagement. Normative and affective commitments predicted work engagement of the lecturing staff at the UNAM.

Employees should be included in the decision-making process and they should be allowed to direct work-related activities and to attend training and development initiatives. Team building should be prioritised to enhance college relations. Regular assessment of job satisfaction can ensure that employees remain committed and engaged at the organisation.

\section{Acknowledgements}

The authors thank all the lecturing staff for taking part in the study and the University of the Free State (UFS) for paying the publishing fees of the article.

\section{Competing interests}

The authors declare that they have no financial or personal relationship(s) that may have inappropriately influenced them in writing this article.

\section{Authors' contributions}

Dr W.R. Pieters was responsible for article writing, data collection and analysis. Prof. E.V. Zyl was responsible for article writing and editing. Prof. P. Nel was responsible for data analysis and editing.

\section{Funding information}

This study was supported by the University of the Free State (publishing of the article).

\section{Data availability statement}

Data sharing is not applicable to this article as no new data were created or analysed in this study.

\section{Disclaimer}

The views and opinions expressed in this article are those of the authors and do not necessarily reflect the official policy or position of any affiliated agency of the authors. 


\section{References}

Afzaal, H.S., \& Afzaal, T. (2013). An investigation of relationship among emotional intelligence, organizational commitment and job satisfaction: Evidence from academics in Brunei Darussalam. International Business Research, 6(3), 217-228. https://doi.org/10.5539/ibr.v6n3p217

Ajala, E.M. (2013). Quality of work life and workers wellbeing: The industrial social workers approach. Ife PsychologylA, 21(2), 46-56.

Allen, N.J., \& Meyer, J.P. (1990). The measurement and antecedents of affective, continuance and normative commitment to the organization. Journal of Occupational Psychology, 63, 1-18.

Allen, N.J., \& Meyer, J.P. (1996). Affective, continuance and normative to the organisation: An examination of the construct validity. Journal of Vocational Behavior, 49(3), 252-276. https://doi.org/10.1006/jvbe.1996.0043

Bakker, A.B. (2011). An evidence-based model of work engagement. Current Directions in Psychological Science, 20(4), 265-269. https://doi.org/10.1177/0963721411414534

Bakker, A.B., \& Demerouti, E. (2008). Towards a model of work engagement. Career Development International, 13(3), 209-222. https://doi.org/10.1108/1362043 0810870476

Bakker, A.B., Schaufeli, W.B., Leiter, M.P., \& Taris, T.W. (2008). Work engagement: An emerging concept in occupational health psychology. Work and Stress, 22(3), 187-200. https://doi.org/10.1080/02678370802393649

Baklaieva, O. (2016). The relationship among meaningfulness of work, work engagement and intention to leave. Unpublished Master's thesis for the Degree of Master of International Marketing, University of Management and Economics, Ukraine.

Barkhuizen, N., \& Rothmann, S. (2006). Work engagement of academic staff in South African higher education institutions. Management Dynamics, 15(1), 38-48.

Brinkmann, R., \& Stapf, K. (2005). Internal termination: If the job becomes the facade. Munchen: C.H. Beck Verlag.

Brown, B.B. (2003). Employees' organizational commitment and their perception of Unpublished PhD dissertation in Human Development. VA: Virginia Polytechnic Institute and State University, Falls Church, Virginia.

Chang, W.., Wang, Y., \& Huang, T. (2013). Work design-related antecedents of turnover intention: A multilevel approach. Human Resource Management, 52(1), 1-26. https://doi.org/10.1002/hrm.21515

Coetzee, M., Schreuder, D., \& Tladinyane, R. (2007). Organisational commitment and its relation to career anchors. Southern African Business Review, 11(1), 65-86.

Creswell, J.W. (2003). Research design: Qualitative, quantitative, and mixed methods approaches (2nd edn.). Thousand Oaks, CA: Sage.

Deci, E.L., \& Ryan, R.M. (2008). Facilitating optimal motivation and psychological wellbeing across life's domains. Canadian Psychology, 49(1), 14-23. https://doi. org/10.1037/0708-5591.49.1.14

Dockel, A., Basson, J.S., \& Coetzee, M. (2006). The effect of retention factors on organisational commitment: An investigation of high technology employees. South African Journal of Human Resource Management, 4(2), 20-28. https://doi. org/10.4102/sajhrm.v4i2.91

Du Plooy, J., \& Roodt, G. (2010). Work engagement, burnout and related constructs as predictors of turnover intentions. South African Journal of Industrial Psychology 36(1), 1-13. https://doi.org/10.4102/sajip.v36i1.910

Etikan, I., Musa, S.A., \& Alkassim, R.S. (2015). Comparison of convenience sampling and purposive sampling. American Journal of Theoretical and Applied Statistics, and purposive sampling. American Journal of Theoretica
5(1), 1-4. https://doi.org/10.11648/j.ajtas.20160501.11

Field, L.K., \& Buitendach, J.H. (2011). Happiness, work engagement and organisational commitment of support staff at a tertiary education institution in South Africa. South African Journal of Industrial Psychology, 37(1), 1-10. https://doi. org/10.4102/sajip.v37i1.946

Fu, W., \& Deshpande, S.P. (2014). The impact of caring climate, job satisfaction, and organizational commitment on job performance of employees in a China's insurance company. Journal of Business Ethics, 124(2), 339-349. https://doi. org/10.1007/s10551-013-1876-y

Greenberg, J. (2011). Behavior in organizations (10th edn.). Upper Saddle River, NJ: Prentice Hall.

Harrison, D.A., Newman, D.A., \& Roth, P.L. (2006). How important are job attitudes? Meta-analytic comparisons of integrative behavioural outcomes and time
sequences. Academy of Management Journal, 49(2), 305-325. https://doi. sequences. Academy of Manag
org/10.5465/amj.2006.20786077

Hulin, C.L. (1991). Adaptation, persistence, and commitment in organizations. In M.D. Dunnette, \& L.M. Hough (Eds.), Handbook of industrial and organizational psychology (2nd ed., Vol. 2, pp. 445-505). Palo Alto, CA: Consulting Psychologist Press.

Janik, M. (2012). Well-being of educators in selected secondary schools in Namibia. Unpublished Doctoral dissertation, Windhoek: University of Namibia.

Joshi, R.J., \& Sodhi, J.S. (2011). Drivers of employee engagement in Indian organisations. The Indian Journal of Industrial Relations, 47(1), 162-182.

Katsaros, K.K., Tsirikas, A.N., \& Bani, S.N. (2014). Exploring employees' perceptions, job-related attitudes and characteristics during a planned organisational change.
International Journal of Business Science and Applied Management, 9(1), 36-50.

Khan, N.R., Awang, M., \& Ghouri, A.M. (2014). Organizational commitment construct: Validity measure using SEM. Science International, 26(2), 897-902.

Kovjanic, S., Schuh, S.C., \& Jonas, K. (2013). Transformational leadership and performance: An experimental investigation of the mediating effects of basic needs satisfaction and work engagement. Journal of Occupational and Organisational Psychology, 86(4), 543-555. https://doi.org/10.1111/joop.12022

Luthans, F. (2005). Organisational behavior (10th ed.). New York: McGraw and Hill.
Manger, T., \& Eikeland, O. (1990). Factors predicting staff's intentions to leave the University. Higher Education, 19(3), 281-291. https://doi.org/10.1007/BF00133893

Marques, L.A. (2013). Antecedents and outcomes of work-related psychological wellbeing of staff members of the University of Namibia. Unpublished Doctoral dissertation, Windhoek: University of Namibia.

Mercurio, Z.A. (2015). Affective commitment as a core essence of organizational commitment: An integrative literature review. Human Resource Developmen Review, 14(4), 389-414. https://doi.org/10.1177/1534484315603612

Mensele, C., \& Coetzee, M. (2014). Job embeddedness, organisational commitment and voluntary turnover of academic staff at a higher education institution in South Africa. South African Journal of Labour Relations, 38(1), 9-30.

Meyer, J.P., Allen, N.J., \& Smith, C. (1993). Commitment to organisations and occupations: Extension and test of a three component model conceptualization. Journal of Applied Psychology, 78(4), 538-551. https://doi.org/10.1037/0021-9010.78.4.538

Mohamed, W.S.E.D. (2016). Investigating the relationship between job satisfaction and organizational citizenship behavior among Beni Suef Cement company employees. Arabian Journal of Business and Management Review, 6(5), 2-7.

Mone, E.M., \& London, M. (2010). Employee engagement through effective performance management: A practical guide for managers. New York: performance management: A practi
Routledge -Taylor and Francis Group.

Mosadeghrad, A.M., \& Ferdosi, M. (2013). Leadership, job satisfaction and organisational commitment in healthcare sector: Proposing and testing a model. Materia Socio Medica, 29(2), 121-126. https://doi.org/10.5455/msm.2013.25.121-126

Nunnally, J.C. (1978). Psychometric theory (2nd edn.). New York: McGraw-Hill.

Oosthuizen, T.F.J., \& Berndt, A.D. (2008). Stress management among academic employees. Journal of Contemporary Management, 5(1), 90-105.

Pallant, J. (2005). SPSS survival manual: A step by step guide to data analysis using SPSS for Windows (Version 12). Sydney: Ligare.

Pieters, W.R. (2015). Psychological empowerment and how it impacts on job satisfaction and organisational commitment of staff members at the University of Namibia (UNAM). Namibia Journal of Managerial Sciences, 1(2), 98-120.

Pretorius, D., Basson, W.J., \& Ogunbanjo, G.A. (2010). Personality profile and coping resources of family medicine vocational trainees at the University of Limpopo, South Africa. South Africa Family Practice, 52(5), 446-450. https://doi.org/10.108 0/20786204.2010.10874023

Rokhman, W. (2010). The effect of Islamic work ethics on work outcomes. JBO Electronic. Journal of Business Ethics and Organization Studies, 15(1), 21-27.

Rothmann, S., Barkhuizen, N., \& Tytherleigh, M.Y. (2008). Model of work-related ill health of academic staff in a South African higher education institution. South African Journal of Higher Education, 22(2), 404-422. https://doi.org/10.4314/ sajhe.v22i2.25794

Rothmann, S., Diedericks, E., \& Swart, J.P. (2013). Manager relations, psychological need satisfaction and intention to leave in the agricultural sector. South African Journal of Industrial Psychology, 39(2), 1-14. https://doi.org/10.4102/sajip.v39i2.1129

Ryan, R.M., \& Deci, E.L. (2000). Self-determination theory and the facilitation of intrinsic motivation, social development and well-being. American Psychologist, 55(1), 68-78. https://doi.org/10.1037/0003-066X.55.1.68

Saks, A.M. (2006). Antecedents and consequences of employee engagement. Journal of Managerial Psychology, 21(7), 600-619. https://doi.org/10.1108/02683940610690169

Sardeshmukh, S.R., Sharma, D., \& Golden, T.D. (2012). Impact of telework on exhaustion and job engagement: A job demands and job resources model. New Technology, Work and Employment, 27(3), 193-207. https://doi.org/10.1111/ j.1468-005X.2012.00284.X

Schaufeli, W., \& Bakker, A. (2004). Utrecht work engagement scale: Preliminary manual. Retrieved from https://www.wilmarschaufeli.nl/publications/Schaufeli/ manual. Retrieved from https://WwW.wilmarschau
Test\%20Manuals/Test_manual_UWES_English.pdf.

Schaufeli, W.B. (2014). What is engagement? In C. Truss, K. Alfes, R. Delbridge, A. Shantz, \& E. Soane (Eds.), Employee engagement in theory and practice (pp. 1-37). London: Routledge.

Schleicher, D.J., Hansen, D., \& Fox, K.E. (2010). Job attitudes and work values. In S. Zedeck (Ed.), APA handbook of industrial and organizational psychology (Vol. 3, pp. 137-190). Washington, DC: APA.

Seppala, P., Mauna, S., Feldt, T., Hakanen, J.J., Kinnunen, U., Tolvanen, A., \& Chaufeli, W.B. (2008). The construct validity of the Utrecht work engagement scale: Multisample and longitudinal evidence. Journal of Happiness Studies, 10(4), 459-481. https://doi.org/10.1007/s10902-008-9100-y

Simons, J.C., \& Buitendach, J.H. (2013). Psychological capital, work engagement and organisational commitment amongst call centre employees in South Africa. South
African Journal of Industrial Psychology, 39(2), 1-12. https://doi.org/10.4102/ sajip.v39i2.1071

SPSS. (2016). Statistical Package for the Social Sciences. (Version 24.0) [Computer software]. Chicago, IL: SPSS Incorporated.

Stander, M.W., \& Rothmann, S. (2010). Psychological empowerment, job insecurity and employee engagement. South African Journal of Industrial Psychology, 36(1) 1-8. https://doi.org/10.4102/sajip.v36i1.849

Takawira, N., Coetzee, M., \& Schreuder, D. (2014). Job embeddedness, work engagement and turnover intention of staff in a higher education institution: An exploratory study. South African Journal of Human Resource Management, 12(1), 1-10. https://doi.org/10.4102/sajhrm.v12i1.524 Tett, R.P., \& Meyer, J.P. (1993). Job satisfaction, organizational commitment, turnover
intention, and turnover: Path analyses based on meta-analytic findings. Personnel Psychology, 46(2), 259-293. https://doi.org/10.1111/j.1744-6570.1993.tb00874.x

Van den Broeck, A., Vansteenkiste, M., De Witte, H., Soenens, B., \& Lens, W. (2010). Capturing autonomy, competence and relatedness at work: Construction and initial validation of the work-related basic psychological need satisfaction scale. Journal of Occupational and Organizational Psychology, 83(4), 981-1002. https:// doi.org/10.1348/096317909X481382 
Van den Broeck, A., Vansteenkiste, M., De Witte, H., \& Lens, W. (2008). Explaining the relationship between job characteristics, burnout, and engagement: The role of
basic psychological need satisfaction. Work and Stress, 22(3), 277-294. https:// basic psychological need satisfaction.
doi.org/10.1080/02678370802393672

Van Zyl, L.E., Deacon, E., \& Rothmann, S. (2010). Towards happiness: Experiences of work-role fit, meaningfulness and work engagement of industrial/organisational worychologists in South Africa. South African Journal of Industrial Psychology, 36(1), 1-8. https://doi.org/10.4102/sajip.v36i1.890

Vansteenkiste, M., Neyrinck, B., Niemiec, C.P., Soenens, B., De Witte, H., \& Van den Broeck, A (2007). On the relations among work value orientations, psychological need satisfaction and job outcomes: A self-determination theory approach. Journal of Occupational and Organisational Psychology, 80(2), 251-277. https:// doi.org/10.1348/096317906X111024
Verstuyf, J., Vansteenkiste, M., Soenens, B., \& Boone, L. (2013). Daily ups and downs in women's binge eating symptoms: The role of basic psychological needs, general self-control and emotional eating. Journal of Social and Clinical Psychology, 32(3), 335-361. https://doi.org/10.1521/jscp.2013.32.3.335

Viljoen, J.P., \& Rothmann, S. (2009). Occupational stress, ill health and organisational commitment of employees at a university of technology. South African Journal of Industrial Psychology, 35(1), 1-11. https://doi.org/10.4102/sajip.v35i1.730

Weiss, H.M. (2002). Deconstructing job satisfaction: Separating evaluations, beliefs and affective experiences. Human Resource Management Review, 12(2), 173-194. https://doi.org/10.1016/S1053-4822(02)00045-1

Wellins, R., \& Concelman, J. (2007). Culture of engagement. Leadership Excellence, 24(2), 19. 